\title{
Efficacy of laboratory tests and ultrasonography in the diagnosis of acute appendicitis in gravid patients according to the stages of pregnancy
}

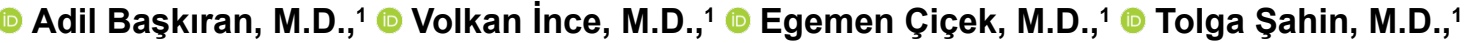

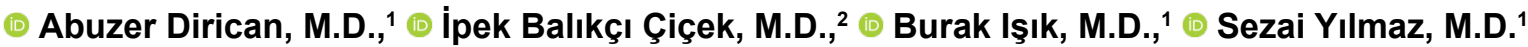

${ }^{1}$ Inönü University, Institute of Liver Transplantation, Turgut Özal Medical Center, Malatya-Turkey
${ }^{2}$ Department of Biostatistics and Bioinformatics, Inönü University Faculty of Medicine, Malatya-Turkey

\begin{abstract}
BACKGROUND: Normal physiologic changes during pregnancy result in similar laboratory and symptomatology changes as those during acute appendicitis (AA), making the diagnosis extremely difficult. The aim of the present study was to analyze the efficacy of conventional laboratory and radiologic tests in the diagnosis of AA according to different stages of pregnancy.
\end{abstract}

METHODS: Twenty-five pregnant patients with pathologically confirmed AA operated at our department between 2012 and 2017 were retrospectively analyzed in terms of changes in conventional laboratory parameters as well as neutrophil-to lymphocyte (NLR) and platelet-to-lymphocyte (PLR) ratios to aid the diagnosis of AA according to different stages of pregnancy.

RESULTS: There were no significant changes in C-reactive protein levels, leukocyte and neutrophil counts, and accuracy of ultrasonography between patients in the first (group I) and second + third trimesters (group 2) ( $>0.05$ ). Lymphocyte count was significantly lower ( $p>0.05)$, whereas NLR and PLR were significantly higher in group $2(p<0.05)$.

CONCLUSION: Laboratory values change significantly during pregnancy, and NLR and PLR seems to be valuable tools for evaluating AA in a stage-specific manner in pregnant patients.

Keywords: Acute appendicitis;neutrophil-to-lymphocyte ratio; platelet-to-lymphocyte ratio; pregnancy.

\section{INTRODUCTION}

The most common non-obstetric surgical emergency in a pregnant patient is acute appendicitis (AA), with its incidence ranging from I/766 to $1 / / 440$. [I] The diagnosis of AA during pregnancy is extremely difficult, and any delay in the diagnosis may result in significant morbidity for the mother and fetus. Therefore, the workup of pregnant patients should be meticulous, and the analysis should be performed in detail. The symptoms and findings encountered during the natural course of pregnancy usually mask the symptoms of AA and make the diagnosis complicated. Leukocytosis [increased white blood cell (WBC) count]; elevated C-reactive protein
(CRP) levels; and symptoms such as nausea, vomiting, and anorexia are frequently encountered in the natural course of pregnancy and make the diagnosis difficult for the physicians. The displacement of the appendix according to the stages of pregnancy makes the ultrasonography evaluation difficult in pregnant women than in normal individuals. Use of abdominal computed tomography is not recommended due to the associated risks of radiation exposure; MRI, although very useful in the diagnosis, is not routinely employed or available at all centers. Alvarado scoring system has not been found to be efficient in the evaluation of pregnant patients due to the associated physiological symptoms. ${ }^{[2]}$

Cite this article as: Başkıran A, İnce V, Çiçek E, Şahin T, Dirican A, Balıkçı Çiçek İ, et al. Efficacy of laboratory tests and ultrasonography in the diagnosis of acute appendicitis in gravid patients according to the stages of pregnancy. Ulus Travma Acil Cerrahi Derg 2018;24:333-336.

Address for correspondence: Adil Başkıran, M.D.

İnönü Üniversitesi Turgut Özal Tıp Merkezi, Karaciğer Nakil Enstitüsü, Malatya, Turkey

Tel: +90 422 - 34l 0660 E-mail: dr.adil.baskiran@gmail.com

Ulus Travma Acil Cerrahi Derg 2018;24(4):333-336 DOI: 10.5505/tjtes.2017.23693 Submitted: 16.08.2017 Accepted: 25.10.2017 Online: 19.06.2018

Copyright 2018 Turkish Association of Trauma and Emergency Surgery 
Uncomplicated AA is associated with a morbidity and mortality of $5 \%$; however, in perforated AA, mortality increases to $40 \%{ }^{[3]}$ McGory et al. ${ }^{[4]}$ have reported a fetal loss rate of $20 \%$ in patients with perforated appendicitis during pregnancy. Furthermore, they reported an increased fetal loss rate in patients in whom negative laparotomies were performed. ${ }^{[4]}$

There is no specific parameter for diagnosing AA. WBC count and CRP levels are the commonly used parameters for diagnosis; however, these are physiologically elevated during pregnancy. WBC count increases with gestational weeks and reaches its peak during labor; therefore, it is not a specific parameter for diagnosing AA in pregnant patients. ${ }^{[5]}$ CRP levels have also been shown to be increased in healthy pregnant women. ${ }^{[6]}$

Because the diagnosis of AA during pregnancy using the conventional diagnostic tests is extremely difficult, the resources for diagnosis should be utilized efficiently and in detail. Yazar et al. ${ }^{[I]}$ reported that neutrophil-to-lymphocyte (NLR) and platelet-to-lymphocyte (PLR) ratios are superior in terms of diagnosis of AA for pregnant patients compared with that for non-pregnant patients.

Physiologic changes are continuous throughout the course of pregnancy (i.e., first, second, and third trimesters). The aim of the present study was to retrospectively analyze the efficacy of conventional laboratory and radiologic tests in the diagnosis of AA according to different stages of pregnancy.

\section{MATERIALS AND METHODS}

\section{Study Design and Allocation of Patients to the Study Groups}

Between 2012 and 2017, pregnant patients who were evaluated in the Emergency Department of the Inonu University Turgut Ozal Medical Center with the suspicion of AA and were operated upon were evaluated, and 25 patients with pathologically confirmed diagnosis of AA were included in the study. All the patients were evaluated by the Department of Gynecology and Obstetrics together with the Department of Surgery. The distribution of the patients according to the stage of pregnancy is summarized in Table I. Because the patient number in the third trimester was low, we formed two study groups: groupl comprising patients in the first trimester and group 2 comprising patients in the second and third trimesters.

Study parameters included WBC count, NLR, PLR and ultrasonography findings that were retrospectively collected from the patient charts. We tried to evaluate the efficacy of each test in diagnosing $A A$ in different stages of pregnancy.

\section{Statistical Analysis}

The distribution of the data was assessed using Shapiro-Wilk test. Data were expressed as median (range) and mean \pm standard deviation. Percentage ratios were provided when necessary. Statistical analysis of the dependent and independent data was performed using Mann-Whitney $U$ test, independent sampling t-test, and Fisher's exact $\chi^{2}$ test. Any $p$ value $<0.05$ was considered significant. During the analysis, Statistical Program for Social Sciences software was used (SPSS v20, IBM, USA).

\section{RESULTS}

The median age of the patients was 25 (19-38) years. The median gestational week was $17(6-31)$ weeks. The median leukocyte count was $12.4(6.3-22.4)$ cells $/ \mathrm{mm} 3$. The median PLR was 235 (10I-404) and median NLR was 5.73 (2.2238.5). The median CRP level was 1.62 (0.33-19.I) $\mathrm{mg} / \mathrm{L}$. Ultrasonography was positive in $60 \%$ of the patients. Neither maternal or fetal loss nor serious complications were observed in our study. The demographic data of the patients are summarized n Table 2.

The distribution of the demographic data according to the study groups are summarized in Table 3 . The changes in the study variables are shown in Figure I. Briefly, the ultrasonog-

Table I. The distribution of the patients according to the stage of pregnancy

\begin{tabular}{lc}
\hline Stage of the pregnancy & Number of patients \\
\hline First trimester (0-14 weeks) & II \\
Second trimester (14-26 weeks) & II \\
Third trimester (26-40 weeks) & 3 \\
Total & 25 \\
\hline
\end{tabular}

Table 2. The demographic data are summarized

\begin{tabular}{|c|c|c|}
\hline & Mean $\pm S D$ & Median (Min.-Max.) \\
\hline Age $(n=25)$ & $26.2 \pm 5.33$ & $25(19-38)$ \\
\hline Neutrophil $(n=25)$ & $10.66 \pm 4.40$ & $9.5(3.3-20.27)$ \\
\hline Lymphocyte (n=25) & $1.66 \pm 0.65$ & I.8 (0.4-3) \\
\hline Platelet $(n=25)$ & $240.6 \pm 69.95$ & $235(101-404)$ \\
\hline$N / L(n=25)$ & $8.8 \pm 8.36$ & $5.73(2.22-38.5)$ \\
\hline PLT/LN (n=25) & $|82.74 \pm| 45.73$ & I49.23 (78.88-765) \\
\hline$M P V(n=25)$ & $9.06 \pm 1.78$ & $8.8(5.4-12.7)$ \\
\hline Gebelik haftası $(n=25)$ & $16.56 \pm 6.91$ & $17(6-31)$ \\
\hline $\operatorname{CRP}(n=25)$ & $4.32 \pm 5.17$ & $1.62(0.33-19.1)$ \\
\hline WBC $(n=25)$ & $13.36 \pm 3.88$ & $12.4(6.3-22.4)$ \\
\hline Yatış süresi $(n=25)$ & $2.44 \pm 2.32$ & $2(1-13)$ \\
\hline
\end{tabular}




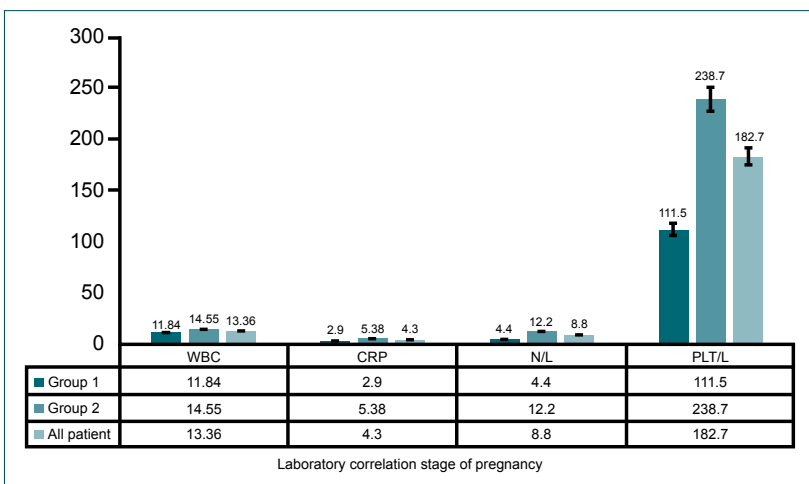

Figure 1. The changes in leukocyte count, CRP levels, and NLR and PLR according to the study groups.

raphy findings did not vary significantly between group $I$ and group 2 ( $p>0.05$ ). Mean platelet volume; neutrophil, platelet, and leukocyte counts; and CRP levels were not significantly different between the study groups $(p>0.05)$. However, lymphocyte counts were significantly lower in group 2 than in group I ( 1.3 vs 2.08 cells $\left./ \mathrm{mm}^{3}, p<0.05\right)$. NLR was significantly higher in group 2 than in group I ( 12.2 vs $4.4, p<0.05)$. The mean PLR in group I and 2 was III.5 and 238.7, respectively, and this difference was significant $(p<0.05)$.

\section{DISCUSSION}

AA is seen in approximately $\mathrm{I}$ in 1700 pregnancies and is most frequently observed in the second trimester of pregnancy. Diagnosis and appropriate management of AA in pregnancy is vital to reduce the potential risks to both mother and fetus. ${ }^{[7]}$ Ueberrueck et al ${ }^{[8]}$ reported an overall appendicitis perforation rate of $14 \%$ in pregnant patients. Furthermore, distri-

Table 3. The demographic data of the study groups are summarized

\begin{tabular}{lcc}
\hline & Group I & Group 2 \\
\hline Number & II & 14 \\
Mean age & 26.9 & 25.6 \\
Mean pregnancy week & 10.3 & 21.4 \\
Mean white blood cell & 11.854 & 14.55 \\
Mean C-reactive protein & 2.9 & 5.38 \\
Mean stay hospital & 2 & 2.7 \\
Mean oral start & 1.2 & 1.07 \\
Mean neutrophil/lymphocyte & 4.4 & 12.2 \\
Mean platelet/lymphocyte & 111.5 & 238.7 \\
Ultrasonography +/- & $7 / 4$ & $8 / 6$ \\
Mean platelet & 227.5 & 250.8 \\
Mean neutrophil & 8.8 & 12.11 \\
Mean lymphocyte & 2.08 & 1.3 \\
Mean mean platelet volume & 9.4 & 8.7 \\
General anesthesia/spinal anesthesia & $6 / 5$ & $12 / 3$ \\
\hline
\end{tabular}

bution of the perforation rates was $8.7 \%, 12.5 \%$, and $26.1 \%$ in first, second, and third trimesters, respectively. They concluded that the diagnosis of appendicitis became more difficult as the pregnancy advanced. The Alvarado scores are usually inconclusive during pregnancy, and there are no validated diagnostic scores or criteria to aid the diagnosis in pregnant patients. ${ }^{[7]} \mathrm{He}$ negative laparotomy rates for appendicitis in pregnant patients were $25 \%-50 \%$, whereas these were $15 \%$ $35 \%$ in non-pregnant counterparts. Mortality associated with appendicitis during pregnancy is a result of complications arising due to delay in the intervention in these patients. Delay in management also possesses considerable risk for the fetus. Fetal loss rate in patients with uncomplicated appendicitis is $1.5 \%-4 \%$; however, it reaches $21 \%-35 \%$ in patients with perforated appendicitis. ${ }^{\left[{ }^{9]}\right.}$

We found that NLR and PLR were particularly increased in second and third trimesters of pregnancy, and this may be used for the diagnosis of $A A$ in this special subgroup of the patients. Recent studies have also suggested NLR and PLR as markers of inflammation and that they can aid the diagnosis of AA in the pregnant patients. When NLR and PLR are combined with WBC count, CRP levels, and lymphocyte count, an accurate diagnosis of AA could be established with a $90.5 \%$ accuracy. ${ }^{[1]}$

Early diagnosis is the best strategy for reducing the complication rates. We aimed to evaluate the efficacy of conventional laboratory tests in the diagnosis of AA according to the stages of pregnancy and observed differences in the levels of abovementioned parameters between patients in the first and second + third trimesters. The low patient number in our study mandated the evaluation of patients in the second and third trimester in the same group. Lymphocyte counts were reduced in the second and third trimesters than in the first trimester, resulting in higher NLR and PLR in the second and third trimesters; this can be used to aid the diagnosis of $A A$ in these patients. Furthermore, the threshold level for NLR and PLR should be reduced for evaluation of the patients in the first trimester.

Uterus becomes an abdominal organ starting from the $12^{\text {th }}$ week of gestation and starts compressing the surrounding viscera. Study results regarding sensitivity of ultrasound during pregnancy vary significantly, and indeterminate results have been reported to be between $7 \%$ and $96 \% .{ }^{[10]}$ This wide variation in the indeterminate results may be due to both operator-dependent and patient-related factors such as the trimester, obesity, and anatomical variations of the appendix. There was no difference regarding the success rate of ultrasonography among group I (63.6\%) and group 2 (57.1\%) in our study.

Laparoscopic appendectomy during pregnancy is associated with low rate of intraoperative complications in all the trimesters. However, it is associated with significantly higher 
rates of fetal loss than appendectomy. ${ }^{\left[{ }^{11}\right]}$ A serious risk associated with laparoscopy in pregnant patients is injury to the gravid uterus. Furthermore, pneumoperitoneum results in absorption of $\mathrm{CO}_{2}$ by both mother and fetus. We chose open approach in all of our patients and performed the surgery through a Mc Burney incision in all of them. Furthermore, we did not encounter any maternal or fetal mortality.

The patient number in our study was low; therefore, we were not able to determine which scoring systems could be effectively used for the diagnosis of AA during pregnancy. To the best of our knowledge, this is the first study to evaluate the efficacy of conventional laboratory techniques as well as NLR and PLR in the diagnosis of AA in different stages of pregnancy. We strongly believe that NLR and PLR will become a part of scoring system specific for the pregnant patient in the diagnosis of AA. This study will serve as a guide for future, multi-institutional, large-volume studies to reach such a goal.

Conflict of interest: None declared.

\section{REFERENCES}

1. Yazar FM, Bakacak M, Emre A, Urfalıoglu A, Serin S, Cengiz E, et al. Predictive role of neutrophil-to-lymphocyte and platelet-to-lymphocyte ratios for diagnosis of acute appendicitis during pregnancy. Kaohsiung J Med Sci 2015;31:591-6. [CrossRef]
2. Liu W, Wei Qiang J, Xun Sun R. Comparison of multislice computed tomography and clinical scores for diagnosing acute appendicitis. J Int Med Res 2015;43:341-9. [CrossRef]

3. Türkan A, Yalaza M, Kafadar MT, Değirmencioğlu G. Acute Appendicitis in Pregnant Women: Our Clinical Experience. Clin Invest Med 2016;39:27521. [CrossRef]

4. McGory ML, Zingmond DS, Tillou A, Hiatt JR, Ko CY, Cryer HM. Negative appendectomy in pregnant women is associated with a substantial risk of fetal loss. J Am Coll Surg 2007;205:534-40. [CrossRef]

5. Lurie S, Rahamim E, Piper I, Golan A, Sadan O. Total and differential leukocyte counts percentiles in normal pregnancy. Eur J Obstet Gynecol Reprod Biol 2008;136:16-9. [CrossRef]

6. Watts DH, Krohn MA, Wener MH, Eschenbach DA. C-reactive protein in normal pregnancy. Obstet Gynecol 1991;77:176-80. [CrossRef]

7. Flexer SM, Tabib N, Peter MB. Suspected appendicitis in pregnancy. Surgeon 2014;12:82-6. [CrossRef]

8. Ueberrueck T, Koch A, Meyer L, Hinkel M, Gastinger I. Ninety-four appendectomies for suspected acute appendicitis during pregnancy. World J Surg 2004;28:508-11. [CrossRef]

9. Brown JJ, Wilson C, Coleman S, Joypaul BV. Appendicitis in pregnancy: an ongoing diagnostic dilemma. Colorectal Dis 2009;11:116-22.

10. Kapan S, Bozkurt MA, Turhan AN, Gönenç M, Alş H. Management of acute appendicitis in pregnancy. Ulus Travma Acil Cerrahi Derg 2013;19:20-4. [CrossRef]

11. Arer İM, Alemdaroğlu S, Yeşilağaç H, Yabanoğlu H. Acute appendicitis during pregnancy: case series of 20 pregnant women. Ulus Travma Acil Cerrahi Derg 2016;22:545-8. [CrossRef]

\section{ORIJINAL ÇALIŞMA - ÖZET}

Gebeliğin evresine göre ultrasonografi ve laboratuvar testlerin akut apandisit tanısına etkisi

Dr. Adil Başkıran, ${ }^{1}$ Dr. Volkan İnce, ${ }^{1}$ Dr. Egemen Çiçek, ${ }^{1}$ Dr. Tolga Şahin, ${ }^{1}$ Dr. Abuzer Dirican, ${ }^{1}$

Dr. İpek Balıkçı Çiçek, ${ }^{2}$ Dr. Burak Işık, ${ }^{1}$ Dr. Sezai Yılmaz ${ }^{1}$

${ }^{1}$ Inönü Üniversitesi Turgut Özal Tıp Merkezi, Karaciğer Nakil Enstitüsü, Malatya

${ }^{2}$ Inönü Üniversitesi Tıp Fakültesi, Biyoistatistik Anabilim Dalı, Malatya

AMAÇ: Gebelik sürecinde olan fizyolojik değişiklikler akut apandisit semptom bulgular ile benzerlik gösterdiği için tanıyı zorlaştırmaktadır. Bu sebeple gebelik süresince tanıya yardımcı olabilecek özgün radyolojik ve laboratuvar testleri yoktur. Bu çalışmada amacımız gebelik trimesterlerine göre laboratuvar ve radyolojik testlerin hangi evrede daha etkili olduğunu araştırmaktır.

GEREÇ VE YÖNTEM: 20I2-20I7 yılları arasında kliniğimizde ameliyat edilen ve patoloji raporlarıyla onaylı akut apandisit tanısı alan gebe hastaların laboratuvar verilerinden nötrofil lenfosit oranı (NLO), platelet lenfosit oranı (PLO) analiz edilerek gebeliğin hangi evrelerinde daha anlamlı olduğu araştırıldı.

BULGULAR: Ortalama yaş 25 (19-38) yıl. Ortalama gebelik haftası I7 (6-3I) ortalama lenfosit sayısı 12.4 (6.3-22.4) hücre/m³ ultrasonografi \%60 hastada apandisit ile uyumlu bulgular saptandı. Lenfosit sayıları, C-reaktif protein değerleri, nötrofil sayıları ve ultrasonografi değerleri açısından I. tirmester (grup I) ve 2 ve 3 üncü trimester (grup 2) hastalar arasında anlamlı bir fark saptanmadı ( $>0.05$ ). Lenfosit sayısı grup 2'de belirgin düşük izlendi ( $p>0.05)$. Nötrofil lenfosit oranı ve PLO oranları grup 2'de belirgin yüksek izlendi $(p<0.05)$.

TARTIŞMA: Gebelik süresince önemli laboratuvar değişiklikleri olmaktadır. Nötrofil lenfosit oranı ve PLO akut apandisit değerlendirmesinde ve gebeliğin evresine göre tanıya kolay ulaşmak için önem kazanmaktadır.

Anahtar sözcükler: Akut apandisit; gebelik; nötrofil lenfosit oranı; platelet lenfosit oranı.

Ulus Travma Acil Cerrahi Derg 2018;24(4):333-336 doi: 10.5505/tjtes.2017.23693 